\title{
The Phenomenon of Migration from the Point of View of the Idea of Developing the Common Home Con- tained in Catholic Social Teaching, Especially as For- mulated by Popes Benedict XVI and Francis Jindřich Šrajer
}

\section{Introduction}

When Václav Havel, the then President of the Czech Republic, characterised the world we live in in his New Year 2001 address and tried to express the putative feelings of not many persons, he spoke of an uneasy to survey, somewhat rough and somewhat crazy world, which is difficult to understand, while at the same time it is possible to doubt the good sense of many things determining its motion. ${ }^{1}$ After the time that has elapsed, it is still possible to regard Havel's words as valid. The contemporary world appears to be sinking deeper and deeper into chaos. It is not easy to find orientation in it, or to discover its true meaning or the origin of things determining its motion. Nonetheless, it is possible to claim with some certainty that terrorism and local military conflicts, as well as poverty and poor living conditions in some parts of the world are the present phenomena stimulating global chaos and fear. ${ }^{2}$ Unprecedented numbers of people are on the move. Some are running away from endangered areas to save their very lives, others because they are looking for a means of livelihood or a new home. ${ }^{3}$ The problem, especially for politicians, is that they can hardly - it is even suspected that sometimes they don't want to - find the true causes of the arisen chaos and effectively solve the associated problems. A strong migration wave is flooding Europe, especially the Western half. As a consequence, Europe is confronted with its humanist roots, which include respect for human dignity and rights, solidarity, helping the needy, etc. Pope Francis notes that in this situation Europe must not betray its own values. ${ }^{4}$

The Church, which throughout her history has regarded the care of foreigners, itinerant people and, since recently, also assistance to immigrants as an important sphere of her social interest,

1 Cf. ( ) Václav HAVEL, Novoroční projev prezidenta ČR, 1. 1. 2001 (on-line), at: http://archive.vaclavhavel-library.org/viewHavelWork_ event.php, accessed 28th May 2016.

2 In this context Pope Francis is not afraid to repeatedly speak of a third world war, which according to him takes place gradually. Cf. (c) Common Declaration of Pope Francis and Ecumenical Patriarch Bartholomew (on-line), at: http://w2.vatican.va/content/francesco/en/ speeches/2014/may/documents/papa-francesco_20140525_terra-santa-dichiarazione-congiunta.html, accessed 9th December 2016.

3 The massive wave of refugees flooding Europe is not backed by war conflicts alone, though essentially it is, but also by worsening conditions of life in the individual countries. According to some, another massive migration wave flooding Europe can be expected in the future due to climatic changes. So the problem of migration is a pressing problem not only of today, but also of tomorrow.

4 Cf. ( ) Joint Declaration of Pope Francis and Ecumenical Patriarch Bartholomew; further cf. FRANCIS, Sním o Evropě jako o matce, Perspektivy, KT 21/2016, p. 7. 
regards migration at the beginning of the third millennium as a significant social phenomenon giving rise to grave social, economic, political, cultural and religious problems, which present dramatic challenges to individual nations as well as to the international community, lacking simple solutions or clear answers. ${ }^{5}$ Before the present culmination of a massive migration wave, unparalleled in Europe in intensity since World War II, texts of Catholic social teaching speak of migration as a social phenomenon of epochal character, requiring courageous and prudent international cooperation policy, which must be based on close cooperation with the migrants countries of origin and countries accepting them. ${ }^{6}$ In this situation the Church regards migration as a 'sign of the times', requiring due attention. ${ }^{7}$

The present treatise reflects on the phenomenon of migration precisely from the positions of Catholic social teaching. It does not and essentially cannot have the ambition to capture the epochal problem of migration in all of its complexity and diversity in several pages. Neither does it aim to present a complex historical outline of the conception of migration in Catholic social teaching in the dynamics of the development and changes of its argumentative lines, which reflect the dynamics of the development of migration and migratory currents in the given periods and historical circumstances and also express the historical development of Catholic social teaching as a whole. ${ }^{8}$ This treatise aims merely to try to view the contemporary problem of migration at the beginning of the third millennium through the eyes of the last two Popes, Benedict XVI and Francis. Both emphasise and to some extent elaborate on or innovate - which is also one of the questions of the present treatise - two important principles that Catholic social teaching employs to justify its attitude towards the issue of migration. In the space delineated by these two principles the discussion of a responsible way to deal with the issue takes place. It involves harmonising the requirements deriving from the uniqueness of human dignity and universal human rights with the right of sovereign states towards corresponding regulation of migration (e.g. by border controls). ${ }^{9}$ The first of the two principles is the cosmopolitan principle (the idea of a common home, one world). The other is the political principle. Pope Benedict XVI develops the former in a specific way, especially with respect to the recent world economic and financial crisis, in the encyclical letter Caritas in veritate (2009). Pope Francis appeals to this principle in his statements not only in relationship to migration, but also in relation to the contemporary ecological issues, which he reflects on in his first social encyclical letter Laudato si' (2015). In my view these two Popes' formulations based on the two principles, especially the cosmopolitan one, and posit questions concerning their justification, or the justification of requirements deriving from them towards solving the problem of migration. In other words, the focus is primarily on the relevancy of the above mentioned solution's necessary preconditions, as formulated by the two Popes. These preconditions are linked to the question of the role or significance of the Christian faith, and of Christians and the Church in the global world, as well as the question as to what extent universal brotherhood can be realised in the world.

5 Cf. Message of His Holiness John Paul II for the Celebration of World Day of Peace January 1st, 2001, (on-line), at: http://w2.vatican.va/ content/john-paul-ii/en/messages/peace/documents/hf_jp-ii_mes_20001208_xxxiv-world-day-for-peace.html, art. 12, 13; Cf. also BENEDICT XVI, Caritas in veritate (on-line), at: http://w2.vatican.va/content/benedict-xvi/en/encyclicals/documents/hf_ben-xvi_ enc_20090629_caritas-in-veritate.html, art. 62. Further only CV and section number.

6 Cf. CV 62.

7 Cf. PONTIFICAL COUNCIL FOR THE PASTORAL CARE OF MIGRANTS AND ITINERANT PEOPLE, Erga migrantes caritas Christi (on-line), at: http://www.vatican.va/roman_curia/pontifical_councils/migrants/documents/rc_pc_migrants_doc_20040514_ erga-migrantes-caritas-christi_en.html, art. 1-11.

8 The issue is comprehensively discussed by Petr ŠTICA, Migrace v sociálním učení církve, AUC THEOLOGICA 1/2012, pp. 113-135.

9 Cf. ibid, p. 128. 


\section{The idea of a common home - universal brotherhood}

The cosmopolitan principle can without doubt be regarded as the basic point of departure and important reference point of a socio-ethical reflection on issues associated with the present migration crisis. ${ }^{10}$ It is good to be aware that understanding the world as one creation of God, as a community of all humans who are principally equal, is at the basis of the Biblical and Christian tradition..$^{11}$ In Catholic social teaching the cosmopolitan principle is closely linked with the personal principle. It is assumed that every human being, created in God's image (cf. Gen 1:27), regardless of state citizenship, which is secondary in this respect, has unique, inalienable dignity. Every human being is a bearer of human rights, which among others excludes all forms of racism or xenophobia. In this respect the Second Vatican Council marks an important dividing line in the history of Christian thought, as it, in accordance with the renewed ecclesiology, reflects a 'new awareness of Christians of the way how to be a true community of the faithful and the people of God'. ${ }^{12}$ This means, among other things, a renewed interest in Catholic social teaching, ${ }^{13}$ and in the needs of contemporary humans and the world, with which the Church solidarises. The most important document of the Second Vatican Council in this respect, the pastoral constitution Gaudium et spes (1965), also reflects on the global context of social reality. It conceives the proposed solutions to social issues - such as, for example, social and economic inequalities among the individual nations and continents or assistance to refugees and immigrants - on the basis of the required solidary international cooperation..$^{14}$ In connection with the issue of a proper interpretation of economic development it also recalls the idea of the universal destination of goods and reinforces the conception of integral human development. ${ }^{15}$

In the tradition of Catholic social teaching the pastoral constitution Gaudium et spes can without doubt, as already indicated, be regarded as a turning point in many respects. ${ }^{16}$ In my view it is especially due to the attitude towards the world and social reality in the process of progressing and deepening globalisation, which reinforces the awareness of a uniting humanity. But it is possible to say that what that pastoral constitution merely hints at finds a new exposition and rich synthesis, as well as an answer to the challenges contained in it in Pope Paul VI's encyclical letter Populorum progressio (1967), which immediately follows up on the Council's ideas, especially on Gaudium et spes. It applies its social teaching to the specific issue of the development and underdevelopment of nations. ${ }^{17}$ The encyclical reflects on the postcolonial period (the disintegration of colonial powers) and the emerging fundamental social geographical conflict between the rich North and the poor

10 Cf. ibid, p. 131.

11 Cf. on this Petr ŠTICA, Cizinec v tvých branách: Biblické podněty pro etickou reflexi migrace, Praha: Karolinum, 2011, pp. 94-104.

12 KONGREGACE PRO KATOLICKOU VÝCHOVU, Sociální nauka církve. Instrukce pro studium a vyučování, Rome, 1988, Brno, 1991, p. 25.

13 John Paul II notes that here the Church's care for summarising and the further development of the social teaching, which permeated the entire Council's work, manifested itself. Cf. JOHN PAUL II, Sollicitudo rei socialis (on-line), at: http://w2.vatican.va/content/john-paul-ii/en/encyclicals/documents/hf_jp-ii_enc_30121987_sollicitudo-rei-socialis.html, art. 6. Further only SRS and section number.

14 Cf. Pastoral constitution Gaudium et spes (on-line), at: http://www.vatican.va/archive/hist_councils/ii_vatican_council/documents/ vat-ii_cons_19651207_gaudium-et-spes_en.html, art. 84-86. Further only GS and section number.

15 Cf. GS 69. The human being is presented here as 'the source, the center, and the purpose of all economic and social life'. (GS 63) According to the Council the main goal of production is to be 'the service of man, and indeed of the whole man with regard for the full range of his material needs and the demands of his intellectual, moral, spiritual, and religious life; this applies to every man whatsoever and to every group of men, of every race and of every part of the world.' (GS 64)

16 On the importance of the document Gaudium et spes cf. Jindřich ŠRAJER, Lucie KOLÁ ǨOVÁ et al., Gaudium et spes. Padesát let poté, Brno: CDK, 2015

17 Cf. SRS 6, 7. 
South. It especially notes that the rich countries subject the poor ones to numerous injustices, humiliation and discrimination, which disables their true development. ${ }^{18}$ In this context Pope Paul VI admonishes rich countries to solidarise with poor ones. ${ }^{19} \mathrm{He}$ does that with reference to the need for the integral development of the human being and the solidary development of humanity, which are two central lines of his encyclical.

The significance of the encyclical letter Populorum progressio consists ultimately precisely in the breadth of outlook with which the 'social question' is treated in it. In this encyclical Catholic social teaching has matured in order to be able to state openly, based on an objective analysis of the world situation, that 'the social question ties all men together, in every part of the world', ${ }^{20}$ and in connection with that also tries to offer a 'directive for action'. ${ }^{21}$ But the decisive contribution of this encyclical, which I want to develop here also with respect to the contemporary problem of migration and immigration, consists primarily in that the worldwide significance of the social question is presented here as a moral reality which concerns every human being. Employing the encyclical's words, 'Today it is most important for people to understand and appreciate, ${ }^{22}$ Pope John Paul II points out that this worldwide matter 'directly concerns the conscience, which is the source of moral decisions. ${ }^{23}$ According to Pope John Paul II, the moral evaluation of the worldwide significance of the social question implies that political leaders, and citizens of rich countries considered as individuals, especially if they are Christians, have the moral obligation, according to the degree of each one's responsibility, to take into consideration, in personal decisions and decisions of government, this relationship of universality, this interdependence which exists between their conduct and the poverty and underdevelopment of so many millions of people. Pope Paul's Encyclical translates more succinctly the moral obligation as the 'duty of solidarity.'. ${ }^{24}$

There is no doubt that the 'moral core' of the encyclical Populorum progressio mentioned above is what Pope Benedict XVI means when he speaks of this encyclical in Caritas in veritate (2009) as of 'the Rerum novarum of the present age' and tries to bring its teaching up to date with respect to the new requirements of the times. ${ }^{25}$

In the encyclical letter Caritas in veritate: On Integral Human Development in Charity and Truth Pope Benedict XVI views the world social reality as a moral reality and focuses primarily on the role of the Church, the specific significance of Christianity and actualising Christian values in the world, without which integral human development is impossible. He starts from the assumption of love as a gift, grace (charis) ${ }^{26}$ which ought to be realised in truth, whereby that truth is 'at the same time the truth of faith and of reason, both in the distinction and also in the convergence of those two cognitive fields. ${ }^{27}$ That allows him not only to point out the dangers of the present world,

18 Cf. PAUL VI, Populorum progressio (on-line), at: http://w2.vatican.va/content/paul-vi/en/encyclicals/documents/hf_p-vi_ enc_26031967_populorum.html, art. 56-66. Further only PP and section number.

19 Cf. PP 45-55.

20 PP 3.

21 SRS 9.

22 PP 3.

23 SRS 9.

24 Ibid.

25 Cf. CV 8.

26 Cf. CV 5. Although the following presentation of the ideas contained in the encyclical CV does not aim at an overall evaluation of this document, it is nonetheless possible to at least refer here to some critical commentaries on its socio-ethical paradigm. Cf. e.g. Gerhard KRUIP, Caritas in veritate. Ein kritischer Kommentar aus sozialethischer Perspektive, Theologie und Glaube 100/2010, pp. 85-107.

27 CV 5. 
but also to analyse or present its prospects. I will now attempt to recall the dangers presented by the Pope and the possible prospects of contemporary humans, or humanity, and the times in more detail with respect to the issue of migration.

Benedict XVI emphasises the 'objective' character of the principle of love in truth, which is constituted by dialogue, communication and community. The truth as logos 'enables men and women to let go of their subjective opinions and impressions, allows them to move beyond cultural and historical limitations and to come together in the assessment of the value and substance of things. ${ }^{28}$ As the Pope writes further, 'In the present social and cultural context, where there is a widespread tendency to relativize truth, practising charity in truth helps people to understand that adhering to the values of Christianity is not merely useful but essential for building a good society and for true integral human development. ${ }^{29}$ Following up on what has been said the Pope at the same time notes that 'Without truth, without trust and love for what is true, there is no social conscience and responsibility, and social action ends up serving private interests and the logic of power, resulting in social fragmentation, especially in a globalized society at difficult times like the present. ${ }^{30}$

So Benedict XVI finds a direct correlation between the dangers of the present time in a world of progressing and deepening globalisation and the greatness of the challenge to the Church and Christians to actualise the principle of love in truth. According to him the danger of the present time consists in that the de facto interdependence of people and nations is not matched by ethical interaction of consciences and minds that would give rise to truly human development. Only in charity, illumined by the light of reason and faith, is it possible to pursue development goals that possess a more humane and humanizing value. The sharing of goods and resources, from which authentic development proceeds, is not guaranteed by merely technical progress and relationships of utility, but by the potential of love that overcomes evil with good (cf. Rom 12:21), opening up the path towards reciprocity of consciences and liberties. ${ }^{31}$

In other words, Pope Benedict XVI wants to point out the universally salvational dimension of human existence, which stimulates human mutuality and solidarity. Practically that means that 'The earthly city is promoted not merely by relationships of rights and duties, but to an even greater and more fundamental extent by relationships of gratuitousness, mercy and communion. ${ }^{32}$ So effort at justice and the common good enlivened by love contributes to the building of the universal city of God, which is the goal of the history of the human family. In an increasingly globalized society, the common good and the effort to obtain it cannot fail to assume the dimensions of the whole human family, that is to say, the community of peoples and nations, in such a way as to shape the earthly city in unity and peace, rendering it to some degree an anticipation and a prefiguration of the undivided city of God. ${ }^{33}$

The emphasis Pope Benedict XVI placed on 'the interconnection between the impetus towards the unification of humanity and the Christian ideal of a single family of peoples in solidarity and fraternity ${ }^{34}$ 
is based on the conviction that 'integral human development is primarily a vocation', ${ }^{35}$ which requires on the one hand an understanding that 'Without the perspective of eternal life, human progress in this world is denied breathing-space. (...) humanity thus loses the courage to be at the service of higher goods, at the service of the great and disinterested initiatives called forth by universal charity. ${ }^{36} \mathrm{On}$ the other hand, according to Benedict XVI, it requires that every human assumes responsibility in a free and solidary manner. So integral human development requires a transcendent vision of the human being, and needs God because only in an encounter with God we are 'able to see in the other something more than just another creature, to recognize the divine image in the other, thus truly coming to discover him or her and to mature in a love that "becomes concern and care for the other". ${ }^{37}$

With respect to the phenomenon of migration as at present one of the key aspects of integral development ${ }^{38}$ these ideas are of undoubtable relevance. If, according to Benedict XVI, integral human development requires a free and solidary acceptance of responsibility on the part of every human being, it means at the same time a rejection of the logic that development, as well as cases of underdevelopment, are accidental or historically necessary and are not grounded in human responsibility. If, according to Paul VI and Benedict XVI, 'the peoples in hunger are making a dramatic appeal to the peoples blessed with abundance', ${ }^{39}$ it is also 'a vocation, a call addressed by free subjects to other free subjects in favour of an assumption of shared responsibility. ${ }^{20}$ So integral development can ultimately reasonably flourish only in an environment of responsible freedom, whether for individuals or nations. ${ }^{41}$ Following up on what has already been said, the two Popes repeatedly emphasise that the causes of underdevelopment need not be found at the material level, but in undesirable dimensions of the human person: 'in the will, which often neglects the duties of solidarity; secondly in thinking, which does not always give proper direction to the will. ${ }^{32}$ This means that 'in the pursuit of development, there is a need for "the deep thought and reflection of wise men in search of a new humanism which will enable modern man to find himself anew".43 But to a much greater extent it requires effort at lived brotherhood among individuals and nations as a manifestation of the transcendent vocation. Precisely the lack of such brotherhood turns out to be the true cause of underdevelopment. ${ }^{44}$ In this context Benedict XVI notes: As society becomes ever more globalized, it makes us neighbours but does not make us brothers. Reason, by itself, is capable of grasping the equality between men and of giving stability to their civic coexistence, but it cannot establish fraternity. This originates in a transcendent vocation from God the Father, who loved us first, teaching us through the Son what fraternal charity is. ${ }^{45}$

The idea of universal brotherhood - one of its manifestations is selflessness ${ }^{46}$ - of which actualisation is contingent on the dimension of Christian faith can without doubt be defended in a theological way. But in my view that does not mean that thereby Benedict XVI wants to say that persons not sharing in the Christian faith cannot take part in it or co-create it. Benedict XVI himself stresses

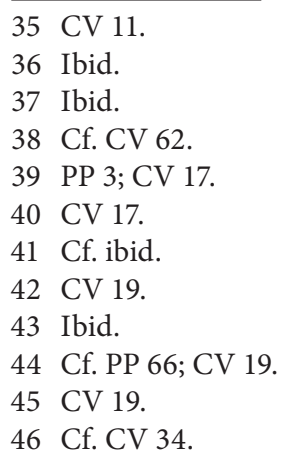


that 'Truth - which is itself gift, in the same way as charity - ... is first of all given to us. (...) charity in truth is a force that builds community, it brings all people together without imposing barriers or limits. ${ }^{47}$ This view may be supported by reference to the offer Benedict XVI, when still Cardinal Ratzinger, made to non-believing friends when he urged them, even if they cannot believe in God, to try and orient their lives as if God existed (veluti si Deus daretur), by which, as he says, 'all our things find the support and measure they so urgently need'. ${ }^{48}$ Similarly inspiring in this respect is also Václav Havel's idea expressed in his New Year's address cited above. In that world which is difficult to survey and somewhat crazy not only for him, he refers to a 'point of much hope', viz. the phenomenon of conscience. He notes that day-by-day faithfulness to the conscience testifies to a moral sensibility and the capability to make ethical judgments in society, in which a thick fabric of positive phenomena and relationships is thereby created, which it is necessary to know of, to speak of and to transform it into stable and durable social realities. Important in Havel's conception is the fact that he points to the transcendent dimension of conscience. In that he speaks of a 'subconscious, deeply rooted assumption that perhaps somewhere everything is known for ever after all and therefore nothing can escape just judgment. We all know', he further says, 'that we ought not to betray our friends, steal, lie, despise someone because his eyes are of different shape or his body disabled, not respect common interests, even though our influence on securing them was very small, and that we ought to think also of what is going on far away or will take place long after. ${ }^{49}$

The facts stated above bring us to a closer understanding of Christianity's specific significance for, or contribution to, the actualisation of universal brotherhood based on the idea of the human race as one family, repeatedly recalled by Benedict XVI, and of the role of Christianity in the context of other cultures and religions and those who don't share in the religious faith. Passing over some other associated matters, ${ }^{50}$ it is possible to highlight here especially the dialogue between faith and reason requested by Benedict, which in his view 'cannot but render the work of charity more effective within society, and it constitutes the most appropriate framework for promoting fraternal collaboration between believers and non-believers in their shared commitment to working for justice and the peace of the human family. ${ }^{51}$ For the faithful this raises the 'duty to unite their efforts with those of all men and women of good will, with the followers of other religions and with non-believers, so that this world of ours may effectively correspond to the divine plan: living as a family under the Creator's watchful eye. ${ }^{32}$ According to Benedict XVI, the best way to actualise brotherly charity and cooperation is the principle of subsidiarity and solidarity, which are particularly suited to 'managing globalization and directing it towards authentic human development..$^{53}$

The emphasis on the cooperation of all people regardless of religious faith in the context of the common home we all share is also present in Pope Francis. This idea is at the foundation of his social encyclical letter Laudato si' (2015), On Care for Our Common Home. In it the Pope deals with all of the relations in which human beings are set, and primarily with their relationship to

48 Joseph RATZINGER, Evropa Benedikta z Nursie v krizi kultur, Kostelní Vydř́í: KNA, 2006, p. 41.

49 () Václav HAVEL, Novoroční projev prezidenta ČR. Cf. on that also FRANCIS, Laudato si'. Bud'pochválen. Encyklika o péči o společný domov, Praha: Paulínky, 2015, art. 212, 232. Further only LS and section number.

50 Cf. on that CV 54-57.

51 CV 57.

52 Ibid.

53 Ibid. 
nature. Although he finds that 'our common home is falling into serious disrepair" ${ }^{54}$ because 'humanity has disappointed God's expectations' ${ }^{55}$ he at the same time expresses hope that 'that there is always a way out, that we can always redirect our steps, that we can always do something to solve our problems ${ }^{5}{ }^{56}$ Pope Francis sees the starting point for the necessary change precisely in 'an awareness of our common origin, of our mutual belonging, and of a future to be shared with everyone ${ }^{257}$ which 'enable the development of new convictions, attitudes and forms of life' ${ }^{58} \mathrm{He}$ speaks of the need for humanity itself to change when he recalls that 'many problems of society are connected with today's self-centred culture of instant gratification. We see this in the crisis of family and social ties and the difficulties of recognizing the other. ${ }^{59}$ In this context Pope Francis urges us to realise that 'we need one another, that we have a shared responsibility for others and the world'.$^{60}$ He points out the fundamental attitude of self-transcendence, which breaks up the isolated and self-referential consciousness and facilitates care for others. ${ }^{61}$

So Pope Francis follows up on ideas contained in the Christian tradition in his own particular way. With respect to migration it is first of all his specific emphasis on charity, on sensitivity for the needy. In this context he notes that 'God's love is meant to reach out to each and every person. Those who welcome the Father's embrace, for their part, become so many other open arms and embraces, enabling every person to feel loved like a child and "at home" as part of the one human family. ${ }^{62} \mathrm{He}$ recalls that 'migrants and refugees challenge us', ${ }^{63}$ they are our brothers and sisters, whereby the experience of divine mercy ought to stimulate us to solidarity with our neighbour as a response to gratuitous divine love. Each of us, as he further notes, is responsible for our neighbours; we are guardians of our brothers, wherever they live. In this context he speaks of a 'culture of encounter', which does away with prejudice and fear and nurtures good personal relationships. It is prepared to give, as well as receive from others. ${ }^{64}$ In Pope Francis's view it is 'the only culture capable of building a better, more just and fraternal world'.65

\section{Migration as a political problem - solution principles}

For Catholic social teaching the cosmopolitan principle presented above and the ideas developed within it are, as already said, the basic starting point defining the political sphere which is entitled or obliged to find adequate solutions for social problems, in the present case the problem of migration. The Church repeatedly reminds it of this right and obligation. Here I will try to formulate some principles or requirements expressed by the social teaching of the Catholic

54 LS 61.

55 Ibid.

56 Ibid.

57 LS 202.

58 Ibid.

59 LS 162.

60 LS 229.

61 Cf. LS 208.

62 (c) FRANCIS, Message of His Holiness Pope Francis for the World Day of Migrants and Refugees, January 17th, 2016 (on-line), at: http:// w2.vatican.va/content/francesco/en/messages/migration/documents/papa-francesco_20150912_world-migrants-day-2016.html, accessed 28th November 2016.

63 Ibid

64 Cf. ibid.

65 (C) FRANCIS, Message of His Holiness Pope Francis for the World Day of Migrants and Refugees (2014). "Migrants and Refugees: Towards a Better World” (on-line), at: http://w2.vatican.va/content/francesco/en/messages/migration/documents/papa-francesco_20130805_ world-migrants-day.html, accessed 28th November 2016. 
Church that ought to be defining for the form such politics takes.

First of all, with respect to the problem of migration, Catholic social teaching with the words of Benedict XVI appeals for a courageous and prudent politics of international cooperation, based on close cooperation with the migrants' countries of origin and the receiving countries. ${ }^{66}$ In other words, the task of the responsible politicians and relevant institutions is to protect the good of all persons, migrants and the population of the countries towards which migrants are heading. It also means perceiving and solving the causes and consequences of migration and the right to regulate it. In this respect Pope Francis has repeatedly criticised political and governmental representatives for the slow speed with which they try to solve the present migration crisis. He believes that it could be prevented and alleviated by adequate steps being taken, ${ }^{67}$ as much as he grants that it is not possible to open doors to refugees in an irrational way ${ }^{68}$ In his view, receiving refugees must be realised with the utmost responsibility. He speaks of erecting bridges, which are built rationally, through dialogue and integration. These bridges are built with policies of 'hospitality and integration, growth, work, economic reform'. ${ }^{69}$

Pope Francis also succeeds in specifying the task of politics, as well as the task of the Church, with respect to the phenomenon of migration by reference to its ambiguity. According to the Pope, migration does often reveal failures and shortcomings on the part of States and the international community, they also point to the aspiration of humanity to enjoy a unity marked by respect for differences, by attitudes of acceptance and hospitality which enable an equitable sharing of the world's goods, and by the protection and the advancement of the dignity and centrality of each human being. ${ }^{70}$

The Church, or Christians, should, according to Pope Francis, be the first - and help others - to see that migrants and refugees do not only represent a problem to be solved, but are brothers and sisters to be welcomed, respected and loved. They are an occasion that Providence gives us to help build a more just society, a more perfect democracy, a more united country, a more fraternal world and a more open and evangelical Christian community. ${ }^{71}$

According to Pope Francis, migration can even 'offer possibilities for a new evangelization, open vistas for the growth of a new humanity foreshadowed in the paschal mystery: a humanity for which every foreign country is a homeland and every homeland is a foreign country. ${ }^{72}$

Finally, Pope Francis notes that solving the present problem of migration requires a deep awareness of solidarity and compassion for those suffering, for people in need, because the causes of migration are socio-economic imbalance and undirected globalisation, which turns people into victims rather than agents. Based on this finding he then calls for 'working together for a better world', which 'requires that countries help one another, in a spirit of willingness and trust, without raising insurmountable barriers. ${ }^{73}$ On the one hand, that should be preceded by 'efforts of

66 Cf. CV 62.

67 Cf. (C) Společné prohlášení papeže Františka a ekumenického patriarchy Bartoloměje.

68 Cf. (c) Papež František pro deník La Croix: Evropa nemůže otevírat brány iracionálně (on-line), at: http://www.radiovaticana.cz/clanek_print.php4?id=23790, accessed 23rd June 2016.

69 (C) RADIO VATICANA, O migraci a exhortaci o rodině (on-line), at: http://www.radiovaticana.cz/clanek_print.php4?id=23617, accessed 23rd June 2016.

70 (C) FRANCIS, Message of His Holiness Pope Francis for the World Day of Migrants and Refugees (2014).

71 Ibid.

72 Ibid.

73 Ibid. 
each country to create better economic and social conditions at home, so that emigration will not be the only option left for those who seek peace, justice, security and full respect of their human dignity. ${ }^{174}$ Creating work opportunities in local economies should also prevent the division of families and guarantee conditions of stability and serenity for individuals and groups. ${ }^{75}$ On the other hand, Pope Francis thinks it is necessary to overcome prejudices and presuppositions in the approach to migration. Not infrequently, the arrival of migrants, displaced persons, asylumseekers and refugees gives rise to suspicion and hostility. There is a fear that society will become less secure, that identity and culture will be lost, that competition for jobs will become stiffer and even that criminal activity will increase. ${ }^{76}$

In this context Pope Francis notes the important role and responsibility of the mass media. Their task is 'to break down stereotypes and to offer correct information in reporting the errors of a few as well as the honesty, rectitude and goodness of the majority.' ${ }^{77}$

\section{Conclusion}

This treatise did not aim to reflect upon the complex issue of migration in an exhaustive manner. Neither did it aim to offer a complex view of the changing attitude of the Church towards this issue within its social teaching. My effort was first of all to present the conceptual depth or breadth of two principles that Catholic social teaching appeals to in order to justify its positions concerning migration. In that I focused especially on reflecting the position of Pope Benedict XVI and Pope Francis, which at present represents the fullest development of these two principles with respect to contemporary social issues, amongst which the urgent problem of mass migration mentioned here inseparably belongs. The treatise has shown that these Popes follow up on the tradition of Catholic social teaching. They update the ideas of Paul VI contained in the encyclical Populorum progressio with respect to contemporary issues, as apparent especially in Benedict XVI. As it has turned out, each does so in a manner peculiar to him. While Benedict XVI underlines especially the irreplaceable role of Christianity, or the principle of love in truth, in forming a humane world and its development, Pope Francis underlines especially the dimension of God's merciful love together with an accent on a special sensitivity to the needs of people in any deprivation. That sensitivity ought to be especially patent in the lives of individual Christians and the Church.

The significance of the so-called cosmopolitan principle reflected upon here highlights especially a fact that was explicitly expressed by Catholic social teaching in Paul VI's encyclical Populorum progressio. It was the first to say that contemporary social issues are on a world scale. This encyclical's main message is that this reality is denoted as a moral reality, which concerns the conscience and responsibility of every human being. That implies the obligation of solidarity, which in this sense means that all feel responsibility for all. ${ }^{78}$ Precisely this emphasis reverberates strongly in the statements of Pope Benedict XVI and Pope Francis. Their statements are valuable, also with respect to the issue of migration, in that they properly differentiate the urgency of the individual challenges and their mutual interconnectedness. On the one hand, they speak of 
the necessity for politicians to actively approach the outlined issues, which must be adequately solved, which in a case like the phenomenon of migration means first of all courageously and also quickly. On the other hand, they emphasise the need to start processes of change in awareness, life attitudes and life styles that concern all.

Taking into account the idea of the unity of the human race and the requirement of universal brotherhood is the fundamental or rather regulative idea from which - in the rendering of Pope Benedict XVI and Pope Francis - important challenges to the realisation of a better world follow. In this respect the phenomenon of migration presents not only a problem, but also a challenge and an opportunity to testify in concreto to that unity of the human race and universal brotherhood. It is especially a challenge for the Church and us Christians, but also for all persons of good will, to unite in a shared effort 'so that this world of ours may effectively correspond to the divine plan' ${ }^{79}$ Here it holds that no one can be regarded as a foreigner who does not deserve acceptance and support. The culture of acceptance and solidarity is the one that indicates the necessity to eradicate inequality, injustice and despotism. ${ }^{80}$ It attests that 'no one is unnecessary, no one is redundant, no one can be written off' ${ }^{81}$ For the host community it also means enriching its identity and the ability to keep developing inclusion, creativity and respect for the dignity of others. $^{82}$

79 CV 57

80 () RADIO VATICANA, Papež účastníkưm Světového kongresu pastorace migrantů: Nikdo není cizinec (on-line), at: http://www.radiovaticana.cz/clanek_print.php4?id=21119, accessed 25th June 2016. 


\title{
The Phenomenon of Migration from the Point of View of the Idea of Developing the Common Home Contained in Catholic Social Teaching, Especially as Formulated by Popes Benedict XVI and Francis
}

\begin{abstract}
:
The study reflects upon the phenomenon of migration from the point of view of Catholic social teaching. It aims to view the contemporary problem of migration at the beginning of the third millennium, especially through the eyes of two Popes - Benedict XVI and Francis - based on reflecting upon two principles engaged by Catholic social teaching to justify its attitude towards migration. One is the cosmopolitan principle (the idea of a common home, one world), and the other is the political principle. In the Popes' view, accounting for the idea of the unity of the human race and the requirement of universal brotherhood is a fundamental idea, or rather an objective to aim for, which gives rise to important challenges towards the realisation of a better world. In this respect the phenomenon of migration presents not only a problem for them, but primarily a challenge and an opportunity to testify to the unity of the human race and universal brotherhood.
\end{abstract}

Keywords: migration, Catholic social teaching, common home, solidarity, integral human development, cosmopolitan principle

\section{Author contact}

\section{Assoc. Prof. Dr. Jindřich Šrajer}

University of South Bohemia, České Budějovice

Faculty of Theology, Department of Ethics, Psychology and Charity Work

Kněžská 8, 37001 České Budějovice

srajer@tf.jcu.cz 